\title{
In vitro assay and morphological characterization of a new product based on diatomaceous earth for lesser mealworm control in poultry houses
}

\author{
Avaliação in vitro e caracterização morfológica de um novo produto à \\ base de terra de diatomáceas visando ao controle do cascudinho dos aviários
}

\author{
Luis Francisco Angeli Alves ${ }^{*}$, Claudecir Castilho Martins', \\ Margaret Seghetto Nardelli ${ }^{1}$, Victor Michelon Alves ${ }^{1}$
}

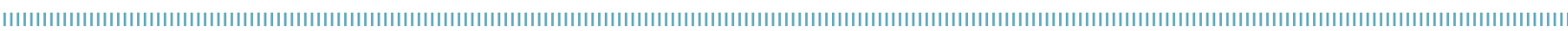

\begin{abstract}
Diatomaceous earth (DE) is an inert powder obtained from milling the fossilized deposits of diatoms. Mainly composed of silica dioxide, DE is highly hygroscopic and is recommended for use in poultry houses as an evironmental conditioner, with a secondary action being the reduction of lesser mealworm populations Alphitobius diaperinus (Panzer). This study aimed to characterize and assess the insecticidal activity of a new environmental conditioner for poultry houses (Poultry $\mathrm{Sec}^{\circledR}$, Vet Science Bio Solution, Maringá, Paraná, Brazil) in the laboratory. The study was conducted by adding DE to poultry feed (1, 2 and $3 \mathrm{~g} \mathrm{DE} / \mathrm{kg}$ feed), as well as by applying the DE to the poultry litter ( 86 and $172 \mathrm{~g} \mathrm{DE} / \mathrm{m}^{2}$ ), with $A$. diaperinus adults $\left(26^{\circ} \mathrm{C}\right.$ in the dark for 10 days). DE samples were analyzed by optical microscopy to measure and count the frustules and to identify the genera of the components. The insecticidal action of the product was observed. When applied to the litter, the DE caused between 83 and $85 \%$ mortality. With respect to the qualitative analysis of the diatoms, we estimated the concentration of $1.2 \times 10^{6}$ individuals/g of the product, distributed in nine distinct genera, with Brachysira Kützing being the predominant genus $(40 \%)$.
\end{abstract}

KEYWORDS: lesser mealworm; alternative control; inert powder.
RESUMO: Terra de diatomáceas (TD) é um pó inerte proveniente da moagem de rochas de depósitos de algas diatomáceas fossilizadas rico em dióxido de sílica. Apresenta-se como um pó fino e altamente higroscópico e é recomendado para uso em aviários de frango de corte como condicionador ambiental, com ação secundária na redução populacional do cascudinho (Alphitobius diaperinus). Este estudo visou avaliar, em laboratório, a atividade inseticida de um novo produto comercializado no Brasil como condicionador ambiental de aviários (Poultry $\mathrm{Sec}^{\circledR}$, Vet Science Bio Solution, Maringá, Paraná, Brasil), bem como caracterizá-lo. O experimento foi conduzido adicionando-se o produto na ração de frango (1, 2 and $3 \mathrm{~g}$ TD/kg ração), e também com a aplicação dele na cama de aviário $\left(86\right.$ e $\left.172 \mathrm{~g} \mathrm{TD} / \mathrm{m}^{2}\right)$. Os insetos adultos foram mantidos nos recipientes com as misturas em $26^{\circ} \mathrm{C}$ no escuro por 10 dias. Amostras do produto foram também analisadas em microscópio óptico visando à contagem e mediçấo das frústulas e identificação das espécies presentes no produto. Quando aplicado sobre a cama, o produto causou entre 83 e $85 \%$ de mortalidade. Foram estimados $1,2 \times 10^{6}$ indivíduos/g do produto, distribuídos em nove gêneros diferentes, com predominância de Brachysira Kützing (40\%).

PALAVRAS-CHAVE: cascudinho dos aviários; controle alternativo; pó inerte. 


\section{INTRODUCTION}

The lesser mealworm (Alphitobius diaperinus) is a worldwide pest of poultry facilities. During its life cycle, larvae live in poultry litter and migrate to the soil for pupation. Adults live in the litter (CHERNAKI; ALMEIDA, 2001). These insects are ingested by the poultry instead of feed, which affects the growth and health of the birds because these insects are also a potential vector of pathogenic bacteria such as Salmonella sp., Campylobacter sp. and Clostridium sp. (SKOV et al., 2004; VITTORI et al., 2007; HAZELEGER et al., 2008; JAPP et al., 2008; CHERNAKI-LEFFER et al., 2010).

This lesser mealworm is controlled by pyrethroid insecticides applied superficially on the poultry litter. In addition to their inefficiency in insect control, environmental and bird health risks are observed with these insecticide applications. Additionally, the emergence of resistant insect populations can occur (GARG et al., 2004; UEMURA et al., 2008; CHERNAKI et al., 2011). Studies with entomopathogenic fungi (ROHDE et al., 2006; ALVES et al., 2015), insecticidal plants (MARCOMINI et al., 2009; ALVES et al., 2012) and inert powders (SANTORO et al., 2010; ALVES et al., 2012) have shown them to be potential alternatives for insect control. Among the latter, highlight is given to diatomaceous earth (DE). It is non-toxic to birds and is used for the control of stored grain pests. The insecticidal action of $\mathrm{DE}$ against the lesser mealworm has been proven in the laboratory (ALVES et al., 2006; JAPP et al., 2008; JAPP et al., 2010).

$\mathrm{DE}$ is highly hygroscopic and it has been recommended as a way to lower the water activity and humidity of poultry litter and to reduce the formation of ammonia, as already demonstrated with other powders that are mixed into the poultry litter (WATSON et al., 2003). At the same time, DE acts on the lesser mealworm by causing abrasions on the protective wax coating on its cuticle, leading to the loss of water from the insect's body, resulting in death (EBLING, 1971; KORUNIC, 1998). Moreover, our previous studies in the laboratory and in a commercial poultry house corroborated by results obtained by LAMBKIN et al. (2012), point to the benefits of using DE in poultry houses.

$\mathrm{DE}$ is made of fossilized diatomaceous algae, composed of amorphous silicon dioxide (YANG et al., 1998; WU et al., 2005 ) with a wide variety of species, morphologies (centrics, penates etc.) and chemical compositions (ROUND et al., 1992; KORUNIC, 1998).

During its processing, $\mathrm{DE}$ is submitted to a calcination process that reduces its moisture, organic material, frustule surface area and density (DOLLEY, 2000). The latter is very important in DE efficiency, being inversely proportional to the hygroscopicity (WU et al., 2005). The hygroscopicity of DE is also due to the very small inner pores of the frustules (EBLING, 1971).

In addition to the hygroscopicity, the DE efficacy is subject to the abrasivity given to the presence of silicon dioxide
(KORUNIC, 1998; KHRAISHEH et al., 2004; WU et al., 2005), the morphology of the predominant frustules and by particle sizes (SOUZA, 1973).

A previous study of different natural samples of DE proved that the physical characteristics of DE, including mineral origin, mineral composition and particles size affect its efficacy in the control of lesser mealworm (JAPP, 2008). In addition, KORUNIC (1997) noted the importance of knowing about the physical and chemical properties of DE as a tool to help experts evaluate the quality of a $\mathrm{DE}$ product. However, nothing is known about characterization of insecticides based on DE in Brazil (most of which are registered for lesser mealworm control). So, it is clear that there is a need for more information about the activity and characterization of $\mathrm{DE}$ products and this pioneer study was carried out to meet this objective.

Experiments were conducted in the laboratory to assess the insecticidal action of the product Poultry $\operatorname{Sec}^{\circledR}$ (Vet Science Bio Solution, Maringá, Paraná, Brazil, www.vetscience.com.br) on the lesser mealworm adults to determine the optimal concentration for insecticidal activity and check its performance as a component in the poultry litter.

Additionally, a microscopic analysis was performed in order to check the size, morphology and density of the skeleton of diatom density.

\section{MATERIAL AND METHODS}

In all bioassays, insects were collected in a commercial poultry house and maintained in the laboratory $\left(26 \pm 1^{\circ} \mathrm{C}, 12 \mathrm{~h}\right.$ photoperiod) in sealed plastic containers with perforated lids, with either poultry litter or poultry feed.

Initially, we performed tests to determine the optimal concentration of Poultry $\mathrm{Sec}^{\circledast}$. The product was evaluated by two different strategies: mixed into poultry feed and mixed into poultry litter. Firstly, Poultry $\mathrm{Sec}^{\circledast}$ was mixed into poultry feed (dried previously at $40^{\circ} \mathrm{C}, 24 \mathrm{~h}$ ) in polyethylene bags under constant stirring for two minutes at doses equivalent to 1,2 and $3 \mathrm{~g}$ of the product $/ \mathrm{kg}$ of poultry feed. After that, the mixture was placed in $10 \mathrm{~cm}$ diameter plastic containers ( $4 \mathrm{~cm}$ depth) and then 30 insects were released in each container (ALVES et al., 2006). We prepared four repetitions for each concentration. Insects were kept on pure poultry feed in control. For all treatments, insects were kept at $26 \pm 1^{\circ} \mathrm{C}$, with a $12 \mathrm{~h}$ photoperiod for 10 days. After that, the dead insects were counted. This experiment was repeated twice.

For the poultry litter experiment, Poultry $\operatorname{Sec}^{\circledR}$ was mixed into the poultry litter at concentrations equivalent to 86 and $172 \mathrm{~g} / \mathrm{m}^{2}$ and distributed in containers as previously described. After that, insects were transferred to the containers and $5 \mathrm{~g}$ of poultry feed was added. This experiment was repeated twice. 
Normal distribution of the mortality data was checked by Shapiro-Wilk test. Data were analyzed by one-way ANOVA and Tukey's test $(\mathrm{p}<0.05)$ (FERREIRA, 2011).

For genus identification and size determination of the diatomaceous frustules (whole or fragmented), permanent slides were prepared and analyzed in a photomicroscope. Digital images were obtained. Identification was made based on KRAMMER; LANGE-BERTALOT (1986; 1991; 1992), KRAMMER (1997a; 1997b), METZELTIN; LANGE-BERTALOT (1998; 2007); METZELTIN et al. (2005); and ROUND et al. (1992). Images were taken and analyzed with AxioVision 4.8 software.

Density was determined using the Uthermöl sedimentation method. Consequently, $0.0025 \mathrm{~g}$ DE samples were added to $10 \mathrm{~mL}$ of distilled water in a sedimentation chamber, as described by UTERMÖHL (1958); MARGALEF (1983); and BICUDO (1990). Density (individuals $/ \mathrm{mL}$ ) was calculated as APHA (1995): $\mathrm{D}=\mathrm{C}(\mathrm{AT} / \mathrm{AF} \times \mathrm{F} \times \mathrm{V})$, in which $\mathrm{D}=$ total density (organisms $/ \mathrm{mL}$ ); $\mathrm{C}=$ number of organisms; $\mathrm{AT}=$ total area of the sedimentation chamber bottom $\left(\mathrm{mm}^{2}\right) ; \mathrm{AF}=$ surface area of the field of counting $\left(\mathrm{mm}^{2}\right) ; \mathrm{F}=$ field counted number; $\mathrm{V}=$ sample volume $(\mathrm{mL})$.

\section{RESULTS AND DISCUSSION}

The efficiency of the Poultry $\operatorname{Sec}^{\circledast}$ was observed, and mortality ranged from $50 \%$ (with the lowest concentration) to $80-90 \%$ (with the two highest concentrations) (Table 1).

Similar results indicating the high insecticidal activity of a commercial product based on DE against the lesser mealworm have already been obtained (mortality above $80 \%$ ) (ALVES et al., 2006; 2008). Also, samples of DE from different

Table 1. Mortality (\%) of lesser mealworm adults that had contact with different dosages of DE in the two application strategies (poultry feed and poultry litter), 10 days after treatment $\left(26^{\circ} \mathrm{C}, 12 \mathrm{~h}\right.$ photophase).

\begin{tabular}{|lc|}
\hline Poultry Sec $^{\circledR}+$ poultry feed & Mortality (\%) \\
\hline $1 \mathrm{~g}$ of product/kg of poultry feed & $53.3 \mathrm{~B}$ \\
\hline $2 \mathrm{~g}$ of product/kg of poultry feed & $90.2 \mathrm{~A}$ \\
\hline $3 \mathrm{~g}$ of product/kg of poultry feed & $83.9 \mathrm{~A}$ \\
\hline Control (poultry feed only) & $0.4 \mathrm{C}$ \\
\hline V.C. (\%) & 22.2 \\
\hline Poultry Sec + poultry litter & Mortality (\%) \\
\hline $86 \mathrm{~g}$ of product $/ \mathrm{m}^{2}$ & $83.6 \mathrm{~A}$ \\
\hline $172 \mathrm{~g}$ of product/m & $85.0 \mathrm{~A}$ \\
\hline Control & $3.5 \mathrm{~B}$ \\
\hline V.C. (\%) & 9.37 \\
\hline
\end{tabular}

Means of mortality followed by the same letter, in each strategy, do not differ significantly by Tukey's test $(p<0.05)$; V.C. $(\%)=$ variation coefficient.
Argentine regions were applied directly to lesser mealworm $\left(63 \mathrm{~g} / \mathrm{m}^{2}\right)$ causing from 7 to $98 \%$ of mortality (JAPP, 2008).

Although the variations on insecticidal activity may be explained by the morphological or chemical characteristics of the poultry litter (ALVES et al., 2008; OLIVEIRA et al., 2009), the differences between the techniques used here and by the JAPP (2008) experiments are notable.

While the products were applied directly to insects by JAPP (2008), in this study, Poultry $\operatorname{Sec}^{\circledast}$ was mixed with poultry feed or poultry litter. This approach simulated field conditions but strongly reduced the contact between the product and the insects. However, the Poultry $\mathrm{Sec}^{\circledast}$ concentration was 20 to $40 \%$ greater than that used by JAPP (2008). Additionally, ALVES et al. (2008) proved by microscope electronic analysis that the wood shavings from poultry litter reduce the transference of DE to insects in comparison to a poultry feed substrate.

$\mathrm{DE}$ is a natural product that is formed from fossilized diatomaceous algae of various shapes and sizes. This is reflected in the different physical characteristics between DE samples from different natural deposits, and it also explains the variations of insecticidal activity of different DE products (KORUNIC, 1998).

Poultry $\mathrm{Sec}^{\circledR}$ was observed to contain particles with frustules of 3 to approximately $50 \mu \mathrm{m}$, and a few of $120 \mu \mathrm{m}$. These sizes are close to the medium particle size found in different commercial DE products, reported by KORUNIC (1998). On the other hand, JAPP (2008) analyzed DE samples from different mines in Argentina, and observed larger particles (500 to 3,000 $\mu \mathrm{m}$ ) than we observed in Poultry Sec ${ }^{\oplus}$. As noted by KORUNIC (1998), particles up to $10 \mu \mathrm{m}$ and higher amounts of amorphous silica are essential for high insecticidal activity, what explains the results obtained with Poultry Sec ${ }^{\circledR}$.

The natural origin of DE also explains the differences in its chemical composition, because the amorphous silica content in DE varies from 60 to 90\% (KORUNIC, 1998). This difference is observed in the tests of DE samples containing 60 to $75 \%$ silicon and the Poultry $\operatorname{Sec}^{\circledR}$ used in this study, which, according to the manufacturer, contains $86 \%$ silicon. In this sense, microscopic analysis proved that Poultry $\mathrm{Sec}^{\circledast}$ has a higher silicon concentration based on the counting of $1.2 \times 10^{6}$ diatom frustules $/ \mathrm{g}$ from very rich silicon diatom species (KORUNIC, 1998). However, KORUNIC (1998) affirms that it is not possible to bind the insecticidal action of DE to silicon concentrations. In this way, JAPP (2008) found that DE samples that were high in silicon were not the most efficient ones. The opposite effect has also been observed.

Thus, it is concluded that the most important factor to determine the activity of $\mathrm{DE}$ is the morphology of the frustules, proving the importance of this study.

Regarding the diatom species that make up Poultry $\mathrm{Sec}^{\circledast}, 322$ frustules from nine different genera were found, with eight belonging to the Bacillariophyceae class and one to the Fragilariophyceae class (pennates frustules). 
Table 2. Diatom genera present in Poultry $\operatorname{Sec}^{\circledR}$ ( $\times 40$ magnification).

\begin{tabular}{lcc} 
Genus / Family & Number of valves & \multicolumn{2}{c}{ Percentage } \\
\hline Brachysira Kützing / Bacillariophyceae & 129 & 40.0 \\
\hline Actinella Lewis / Bacillariophyceae & 58 & 18.2 \\
\hline Eunotia Ehrenberg / Bacillariophyceae & 72 & 22.4 \\
\hline Navicula Bory / Bacillariophyceae & 23 & 6.9 \\
\hline Frustulia Agardh / Bacillariophyceae & 29 & 9.2 \\
\hline Pinnularia Ehrenberg / Bacillariophyceae & 4 & 1.2 \\
\hline Nitzschia Hassall / Bacillariophyceae & 3 & 0.9 \\
\hline Encyonema Kützing / Bacillariophyceae & 2 & 0.6 \\
\hline Staurosirella Williams \& Round / Fragilariophyceae & 2 & 0.6 \\
\hline
\end{tabular}
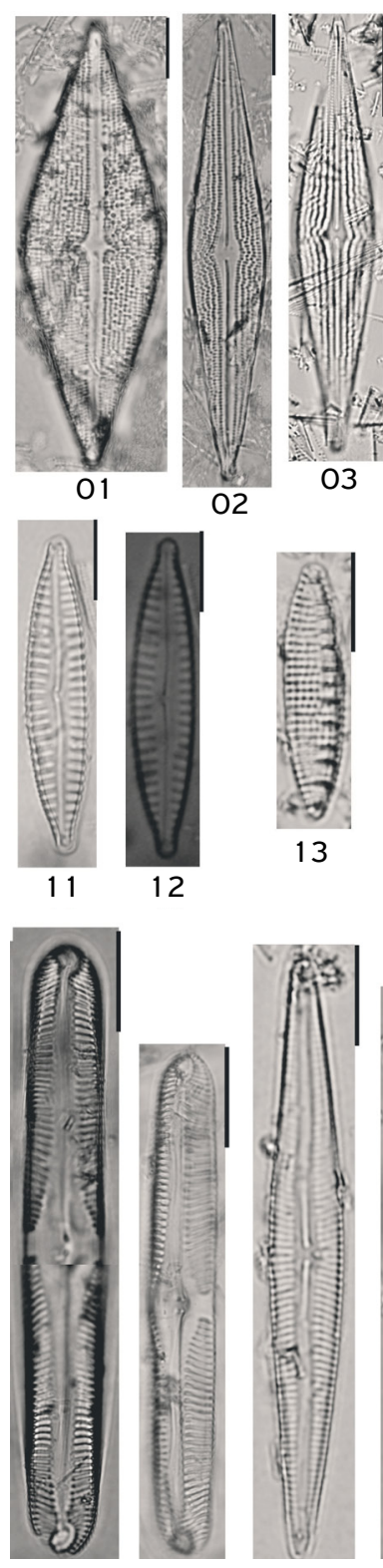

23

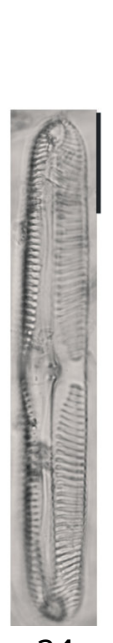

24

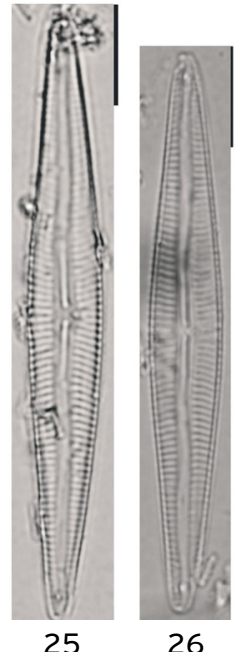

25

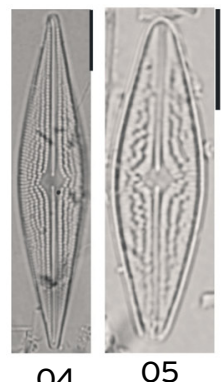

04
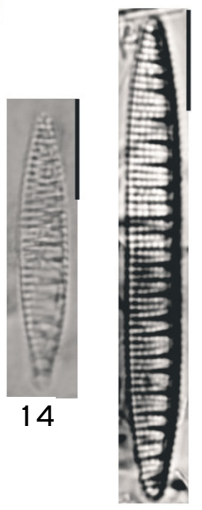

15

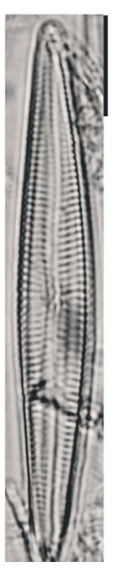

27
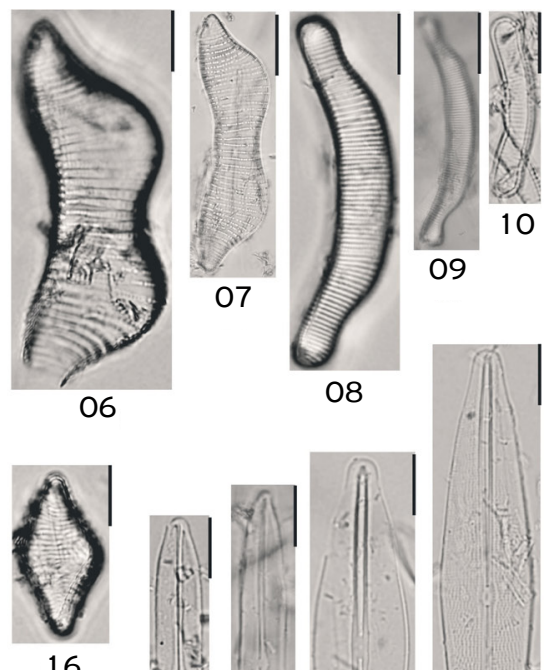

16

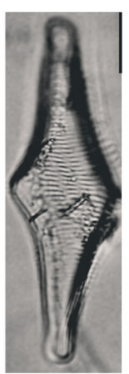

17

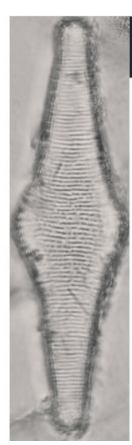

18
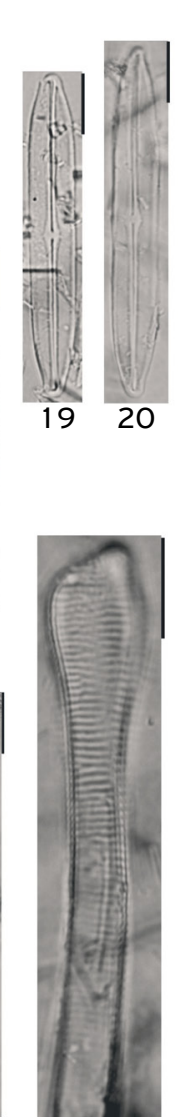

28

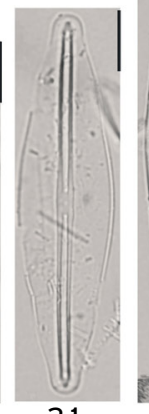

21

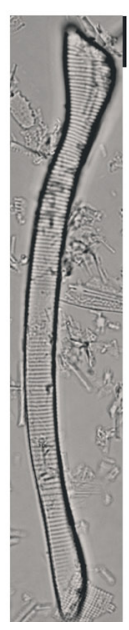

29

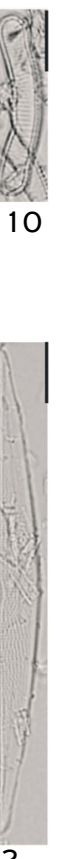

22

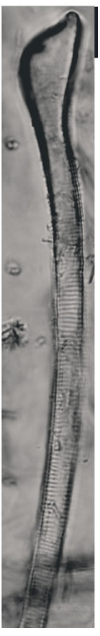

30

Figure 1. Diatom genera observed in the sample of Poultry $\left.\operatorname{Sec}^{\circledR}: 1-5\right)$ Brachysira Kützing; 6-10) Eunotia Ehrenberg; 11-12) Encyonema Kützing; 13-15) Nitzschia Hassall; 16-18) Staurosirella Williams \& Round; 19-22) Frustulia Agardh; 23-24) Pinnularia Ehrenberg; 25-27) Navicula Bory; 28-30) Actinella Lewis (× 1000). 
Additionally, the genus Brachysira Kützing was the most prevalent one (40\%) (Table 2, Fig. 1). Contrary to the results reported by JAPP (2008), Coscinodiscophyceae species (centrics frustules) were not found.

As previously discussed, the technique used to mix the Poultry $\operatorname{Sec}^{\circledast}$ into the poultry litter leads to dispersion, and scanning electron microscopy proved that wood shaving poultry litter is more efficient than poultry feed in removing DE from the lesser mealworm body surface (ALVES et al., 2008). Although DE was more dispersed in the litter substrate, the insecticide efficiency was not affected.

Thus, the efficiency of Poultry $\mathrm{Sec}^{\circledR}$ is probably due to the uniformity and small size of the particles $(3-50 \mu \mathrm{m})$, which is essential to give Poultry $\mathrm{Sec}^{\circledast}$ mobility in poultry litter wood shavings. In this way, DE is physically stable and will affect insects as long as it is dry and in sufficient concentration to ensure that the insects come in contact with enough diatom particles (KORUNIC, 1998).

Although there are several products based on DE recommended for insect control, there are very few products for lesser mealworm control. JAPP (2008) and the results from this study indicate that the diatomaceous composition changes between products from different parts of the word. In Brazil, the total lack of technical information available on commercialized products based on DE makes comparisons difficult. The data obtained here and corroborated by JAPP (2008) highlight the importance of the physical characterization as one of the main reasons for the variations in tests results, regarding the efficiency of DE-based products.

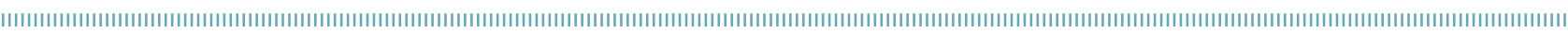
REFERENCES

ALVES, L.F.A.; BUSARELLO, G.D.; OLIVEIRA, D.G.P.; ALVES, S.B. Ação da terra de diatomácea contra adultos do cascudinho Alphitobius diaperinus (Panzer, 1797) (Coleoptera: Tenebrionidae). Arquivos do Instituto Biológico, São Paulo, v.73, p.115-118, 2006.

ALVES, L.F.A.; OLIVEIRA, D.G.P.; NEVES, P.M.O.J. Fatores que afetam a eficiência da Terra de Diatomácea no controle de adultos de Alphitobius diaperinus (Panzer) (Coleoptera: Tenebrionidae). Neotropical Entomology, Londrina, v.37, p.716-722, 2008.

ALVES, V.M.; ALVES, L.F.A.; UEMURA-LIMA, D.H. Atividade da torta de nim sobre adultos do cascudinho dos aviários em condições de laboratório. Ciência Rural, Santa Maria, v.42, p.888-893, 2012.

ALVES, L.F.A.; OLIVEIRA, D.G.P.; LAMBKIN, T.; BONINI, A.K.I.; ALVES, V.M.; PINTO, F.G.S.; SCUR, M.C. Beauveria bassiana applied to broiler chicken houses as biocontrol of Alphitobius diaperinus Panzer (Coleoptera: Tenebrionidae), an avian pathogens vector. Brazilian Journal of Poultry Science, Campinas, v.17, p.459466, 2015.

APHA. AMERICAN PUBLIC ASSOCIATION. Standart methods for the examination of water and wasterwater. 19. ed. Washington, D.C.: APHA, 1995.

BICUDO, D.C. Considerações sobre metodologias de contagem de algas do perifíton. Acta Limnologica Brasiliensia, São Paulo, v.3, p.459-475, 1990.

CHERNAKI, A.M.; ALMEIDA, L.M. Exigências térmicas, período de desenvolvimento e sobrevivência de imaturos de Alphitobius diaperinus (Panzer) (Coleoptera: Tenebrionidae). Neotropical Entomology, Londrina, v.30, p.365-368, 2001.

CHERNAKI-LEFFER, A.M.; KUTTEL, J.; MARTINS, L.M.; PEDROSO, A.C.; ASTOLFI-FERREIRA, C.S.; FERREIRA, F.; PIANTINO-FERREIRA, A.J. Vectorial competence of larvae and adults of Alphitobius diaperinus in the transmission of Salmonella Enteritidis in poultry. Vector-Borne and Zoonotic Diseases, New Rochelle, v.10, p.481487, 2010.
CHERNAKI, A.M.; SOSA-GOMEZ, D.R.; ALMEIDA, L.M.; LOPES, I.O.N. Suscetibility of Alphitobius diaperinus to cypermethrin, dichlorvos and triflumuron in Southern Brazil. Revista Brasileira de Entomologia, Curitiba, v.55, p.125-128, 2011.

DOLLEY, T.P. Diatomite. U.S. Geological Survey Minerals Yearbook, v.25, p. 1-6, 2000.

FERREIRA, D.F. Sisvar: a computer statistical analysis system. Ciência e Agrotecnologia, Lavras, v.35, p.1039-1042, 2011.

GARG, U.K.; PAL A.K.; JHA, G.J.; JADHAO, S.B. Pathophysiological effects of chronic toxicity with synthetic pyrethroid, organophosphate and chlorinated pesticides on bone health of broiler chicks. Toxicologic Pathology, Research Triangle Park, v.32, p.364-369, 2004.

HAZELEGER, W.C.; BOLDER, N.M.; BEUMER, R.R.; JACOBSREITSMA, W.F. Darkling Beetles (Alphitobius diaperinus) and Their Larvae as Potential Vectors for the Transfer of Campylobacter jejuni and Salmonella enterica Serovar Paratyphi B Variant Java between Successive Broiler Flocks. Applied and Environmental Microbiology, Washington, v.74, p.6887-6891, 2008.

JAPP, A.K. Influência do Alphitobius diaperinus (Panzer, 1797) (Coleoptera, Tenebrionidae) no desempenho zootécnico de frangos de corte e avaliação da terra de diatomácea como estratégia para o seu controle. 51 p. Dissertação (Mestrado em Ciências Veterinárias) - Universidade Federal do Paraná, Curitiba, 2008.

JAPP, A.K.; HUBER, R.M.; SANTOS, S.; MEURER, R.; BICHO C.L.; SILVA, A.V.F. Interferência no ganho de peso de frangos de corte alimentados com cascudinhos Alphitobius diaperinus Panzer (Coleoptera: Tenebrionidae). Revista Brasileira de Ciência Avícola, Campinas, v.10, p.170, 2008.

JAPP, A.K.; BICHO, C.L.; SILVA, A.V.F. Importância e medidas de controle para Alphitobius diaperinus em aviários. Ciência Rural, Santa Maria, v.40, p.1668-1673, 2010. 
KHRAISHEH, M.A.M.; AL-DEGS, Y.S.; MCMINN, W.A.M. Remediation of wastewater containing heavy metals using raw and modified diatomite. Chemical Engineering Journal, Cambridge, v.99, p.177-184, 2004.

KORUNIC, Z. Diatomaceous earths, a group of natural insecticides. Journal of Stored Products Research, Manhattan, v.34, p.8797, 1998.

KORUNIC, Z. Rapid assessment of the insecticidal value of diatomaceous earths without conducting bioassays. Journal of Stored Products Research, Manhattan, v.33, p.2 19-229, 1997.

KRAMMER, K.; LANGE-BERTALOT, H. (Eds.). Naviculaceae: neue und wenig bekannte Taxa neue Kombinationen und Synonyme sowie Bemerkungen zu einigen Gattugen. Bibliotheca Diatomologica. Berlin: Koeltz Scientific Books, 1986. 229p.

KRAMMER, K.; LANGE-BERTALOT, H. (Eds.). Bacillariophyceae: Centrales, Fragilariaceae, Eunotiaceae. Süsswasser flora von Mittleleuropa. Berlin: Koeltz Scientific Books, 1991. 576p.

KRAMMER, K.; LANGE-BERTALOT, H. (Eds.). Pinnularia: eine Monographie der europäischen. Bibliotheca Diatomologica Taxa I. Berlin: Koeltz Scientific Books, 1992. 353p.

KRAMMER, K. (Ed.). Die cymbelloiden Diatomeen: eine monographie der weltweit bekannten. Bibliotheca Diatomologica Taxa I. Berlin: Koeltz Scientific Books, 1997a. 382p.

KRAMMER, K. (Ed.). Die cymbelloiden Diatomeen: eine monographie der weltweit bekannten. Bibliotheca Diatomologica Taxa II. Berlin: Koeltz Scientific Books, 1997b. 469p.

LAMBKIN, T.A.; SWAIN, A.J.; RICE, S.J.; BARTLETT, J.S.; ZALUCKI, M.P. Field Assessments of Control Agents for Lesser Mealworm (Coleoptera: Tenebrionidae) Using Litter Sampling. Journal of Economic Entomology, Riverside, v.105, p.979-987, 2012.

MARCOMINI, A.M.; ALVES, L.F.A.; BONINI, A.K.; MERTZ, N.R.; SANTOS, J.C. Atividade inseticida de extratos vegetais e do óleo de neem sobre Adultos de Alphitobius diaperinus Panzer (Coleoptera, Tenebrionidae). Arquivos do Instituto Biológico, São Paulo, v.76, p.413-420, 2009.

MARGALEF, R. Limnologia. Barcelona: Omega; 1983. 1010p.

METZELTIN, D.; LANGE-BERTALOT, H. (Eds.). Tropical Diatoms of South America I. Iconographia Diatomologica. Germany: Koeltz Scientific Books, 1998. 220p.

METZELTIN, D.; LANGE-BERTALOT, H.; GARCÍA-RODRIGUES, F. (Eds.). Diatoms of Uruguay. Iconographia Diatomologica. Germany: Koeltz Scientific Books, 2005. 736p.

METZELTIN, D.; LANGE-BERTALOT, H. (Ed.). Tropical diatoms of South America II. Iconographia Diatomologica. Germany: Koeltz Scientific Books, 2007. 320p.
OLIVEIRA, D.G.P.; ALVES, L.F.A.; MARCHESE, L.P.C.; THOMAZONI, D. Persistência da ação inseticida e repelência da Terra de Diatomácea para cascudinho de aviário Alphitobius diaperinus (Panzer, 1797) (Coleoptera: Tenebrionidae). Semina, Londrina, v.30, p.201-210, 2009.

ROHDE, C.; ALVES, L.F.A.; NEVES, P.M.O.J.; ALVES, S.B.; SILVA, E.R.L.; ALMEIDA, J.E.M. Seleção de isolados de Beauveria bassiana (Bals.) Vuill. e Metarhizium anisopliae (Metsch.) Sorok. contra o cascudinho Alphitobius diaperinus (Panzer) (Coleoptera: Tenebrionidae). Neotropical Entomology, Londrina, v.35, p.231-240, 2006.

ROUND, F.E.; CRAWFORD, R.M.; MANN, D.G. The diatoms. Biology and morphology of the genera. New York: Cambridge University Press, 1992. 747p.

SANTORO, P.H.; NEVES, P.M.O.J.; AMARO, J.T.; CONSTANSKI, K.; LÓPEZ, E.A.L.; ALVES, L.F.A. Associação de pós inertes com fungo entomopatogênico para o controle do cascudinho (Alphitobius diaperinus). Ciência Rural, Santa Maria, v.40, p.1354-1359, 2010.

SKOV, M.N.; SPENCER, A.G.; HALD, B.; NAUERBY, B.; CARSTENSEN, B.; MADSEN, M. The role of litter beetles as potential reservoir for Salmonella enterica and thermophilic Campylobacter spp. between broiler floks. Avian Diseases, Jacksonville, v.48, p.9-18, 2004.

SOUZA, J.F. Perfil analítico da diatomita. Rio de Janeiro: Departamento Nacional da Produção Mineral, 1973. 27p. (Boletim 11).

UTERMÖHL, H. Zur Vervollkommung der Quantitativen Phytoplankton Methodik. Internationale Vereinigung für Theoretische und Angewandte Limnologie, Mitteilungen, v.9, p.1-38, 1958.

UEMURA, D.H.; ALVES, L.F.A.; OPAZO, M.A.U.; ALEXANDRE, T.M.; OLIVEIRA, D.G.P.; URSI, M.V. Distribuição e dinâmica populacional do cascudinho Alphitobius diaperinus (Coleoptera: Tenebrionidae) em aviários de frango de corte. Arquivos do Instituto Biológico, São Paulo, v.75, p.429-435, 2008.

VITTORI, J.; SCHOCKEN-ITURRINO, R.P.; TROVÓ, K.P.; RIBEIRO, C.A.M.; BARBOSA, G.G.; SOUZA, L.M.; PIGATTO, C.P. Alphitobius diaperinus como veiculador de Clostridium perfingens em granjas avícolas do interior paulista - Brasil. Ciência Rural, Santa Maria, v.37, p.894-896, 2007.

WATSON, D.W.; DENNING, S.S.; ZUREK, L.; STRINGHAM, S.M.; ELLIOTT, J. Effects of lime hydrate on the growth and development of darkling beetle, Alphitobius diaperinus. International Journal of Poultry Science, Faisalabad, v.2, p.91-96, 2003.

WU, J.; YANG, Y.S.; LIN, J. Advanced tertiary treatment of municipal wastewater using raw and modified diatomite. Journal of Hazardous Materials, Buffalo, v. 127, p. 196-203, 2005.

YANG, H.S.; LEE, W.J.; CHEN, S.J.; LAI, S.O. PAH emission from various industrial stacks. Journal of Hazardous Materials, Buffalo, v.60, p.159-174, 1998. 